\title{
ANALISIS TINGKAT KEPUASAN KARYAWAN TERHADAP SOFTWARE CLIPPER PADA PT. PRIMAJASA
}

\author{
Suryanto \\ e-mail : Suryanto1865@yahoo.com
}

Diterima :20 Juli 2010/Disetujui : 12 Agustus 2010

\begin{abstract}
Penelitian ini bertujuan untuk mengukur tingkat kepuasan karyawan di bagian keuangan pada PT.Primajasa terhadap software CLIPPER. Metode penelitian yang digunakan adalah metode pengumpulan data. Metode pengumpulan data dilakukan dengan cara riset kepustakaan dan riset lapangan yang menggunakan kuesioner. Untuk metode analisis data digunakan alat bantu software SPSS (Statistical Product and Service Solution) versi 10.0 dan Microsoft Excel untuk mendapatkan hasil dari kuesioner yang telah dibagikan.Populasi yang digunakan adalah karyawan PT.Primajasa, pada bagian keuangan. Hasil yang dicapai adalah terdapat mean harapan sebesar 3,77 dan mean kenyataan sebesar 3,17 yang berarti terdapat gap sebesar -0.6. Disimpulkan bahwa karyawan merasa tidak puas akan kinerja software CLIPPER, maka perusahaan berusaha unutk meningkatkan kinerja software CLIPPER dengan cara maintenance dan upgrade software CLIPPER secara berkala.
\end{abstract}

Kata Kunci : Analisis, Tingkat Kepuasan Karyawan

\section{Latar Belakang}

Sekarang ini banyak perusahaan mengembangkan aplikasi sistem informasi sesuai dengan bidang bisnis yang mereka kembangkan, salah satunya adalah perusahaan jasa transportasi yang melayani kepentingan masyarakat. Seperti pada PT. Primajasa yang merupakan salah satu perusahaan yang bergerak dalam bidang jasa transportasi dengan rute Jakarta dan sekitarnya.

1. Dosen Jurusan Komputerisasi Akuntansi, Universitas Bina Nusantara

J1. K.H. Syahdan No. 9, Palmerah, Jakarta Barat, 11480 
PT.Primajasa mulai menggunakan sistem informasi yang dikembangkan sesuai dengan kebutuhan dari perusahaan itu sendiri. Penggunaan sistem informasi yang dilakukan lima tahun terakhir ini masih mempunyai beberapa kendala dan permasalahan, diantaranya :

a. Data dan laporan keuangan yang diperoleh tidak sesuai standar akuntansi

b. Penggunaan software tidak dapat menghemat waktu dalam pelaporan keuangan

c. Software tidak dapat melakukan perhitungan dengan tepat

Maka melalui penelitian ini diharapkan dapat diketahui sampai sejauh mana kemampuan dan kepuasan software Clipper yang telah digunakan

\section{Identifikasi Masalah}

a. Seberapa tingkat kepuasan user bagian keuangan terhadap software "Clipper".?

b. Bagaimana kinerja software clipper di bagian keuangan pada PT.Primajasa ?

\section{Ruang Lingkup}

Ruang lingkup penelitian ini adalah:

Perusahaan yang diteliti merupakan perusahaan yang bergerak dibidang jasa transportasi yaitu, PT.Primajasa yang beralamatkan di di Jalan REMartadinata KM.7 No.19 Ciputat Tangerang 15400.

a. Mengukur tingkat kepuasan para karyawan bagian keuangan PT. Primajasa terhadap software "Clipper".

b. Mengukur kinerja atas software Clipper yang digunaolehkan Oleh PT. Primajasa

\section{Landasan Teori \\ Kepuasan User}

Dalam penelitian ini yang dimaksud dengan user adalah para pengguna software "Clipper" pada PT.Primajasa .

Menurut Kotler (2003, p61) bila kenyataan tidak sesuai dengan harapan, maka user tidak puas, begitu pula sebaliknya.

Menurut Remenyi (2000, p153), Kepuasan user secara umum dianggap sebagai hasil perbandingan antara pengharapan/kebutuhan user atas sistem informasi dan kinerja sistem informasi yang diterima. 


\section{Kualitas Software}

Menurut Pressman yang dikutip dari buku Galin (2004, p25), Kualitas software digambarkan sebagai pemenuhan kebutuhan secara eksplisit pada bagian pelaksanaan dan fungsional, standar eksplisit dari pengembangan dokumen, dan karakteristik implisit yang diharapkan dari aplikasi yang dikembangkan secara professional.

Menurut IEEE yang dikutip dari buku Galin (2004, p24), kualitas software adalah :

a. Tingkat dimana suatu sistem, komponen, atau proses telah memenuhi dengan kebutuhan-kebutuhan yang spesifik.

b. Tingkat dimana suatu sistem, komponen, atau proses telah memenuhi kebutuhan atau harapan dari user.

\section{Analisis Gap}

Menurut Remenyi (2000, p156-157), pada analisis Gap terdapat beberapa model yang pernah diungkapkan mengenai keputusan informasi user (User Information Satisfaction/UIS). Metode analisis Gap yang digunakan adalah Model Miller \& Doyle.

Dasar yang digunakan untuk pengambilan keputusan dalam analisis gap adalah sebagai berikut:

a. Jika nilai gap berada dibawah garis $X=0$ (bernilai negatif), maka dapat disimpulkan bahwa pada variabel-variabel tersebut, kinerja aplikasi tidak memenuhi harapan user (user merasa tidak puas).

b. Jika nilai gap tepat berada pada $\mathrm{X}=0$, maka dapat disimpulkan bahwa pada variabel-variabel tersebut, kinerja aplikasi telah memenuhi sama dengan harapan user (user merasa puas).

c. Jika nilai gap berada diatas garis $\mathrm{X}=0$ (bernilai positif), maka dapat disimpulkan bahawa pada variabel-variabel tersebut, kinerja aplikasi telah memenuhi lebih dari harapan user (user merasa sangat puas).

Menurut http://library.gunadarma.ac.id/files/disk1/3/jbptgunadar ma-gdl-s22004-arivianipe-127-bab3.pdf analisis gap adalah analisa yang dilakukan untuk mengetahui apakah terdapat perbedaan antara tingkat kepentingan suatu dimensi layanan dengan kinerja aktual layanan tersebut.

\section{Diagram Kartesius}

Menurut Supranto (2001, p242), diagram kartesius terdiri dari suatu bangun yang dibagi atas empat bagian yang dibatasi oleh dua garis yang memotong tegak lurus pada titik-titik $(\mathrm{X}, \mathrm{Y})$, dimana $\mathrm{X}$ merupakan rata-rata hitung dari rata-rata skor 
tingkat pelaksanaan atau kepuasan user seluruh faktor atau indikator dan Y adalah rata-rata skor tingkat kepentingan seluruh faktor yang mempengaruhi kepuasan $u s e r$. Dan rumus yang digunakan adalah:

$$
\overline{\bar{X}}=\frac{\sum \overline{X_{i}}}{\mathrm{i}=1}
$$

$$
\overline{\bar{Y}}=\frac{\sum_{i=1}^{\sum} \bar{Y} i}{K}
$$

Dimana $\mathrm{K}=$ Banyaknya faktor atau indikator yang dapat mempengaruhi kepuasan user.

Kepuasan konsumen dapat dianalisis dari dua dimensi, yaitu dari tahapantahapan atas sesuatu dan kenyataan-kenyataan yang diterima user. Data dari hasil kuisioner dimasukan nilainya pada diagram kartesius. Bila berada pada kuadran A,B,C atau D, maka komponen yang ditanyakan akan memiliki arti masing-masing seperti yang dipaparkan

Gambar Diagram Kartesius

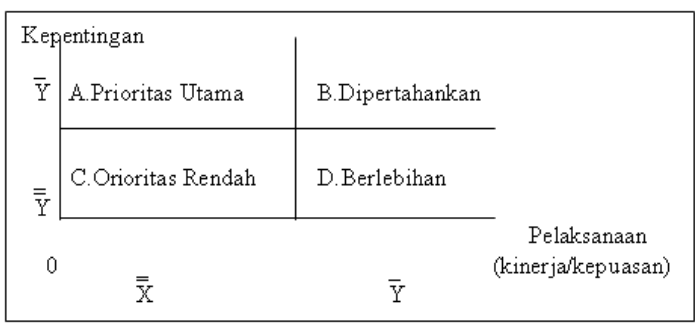

Pembahasan

Pengolahan Terhadap Data Yang Terkumpul

Table Analisis Gap software Clipper per variabel

\begin{tabular}{|c|c|c|c|c|c|}
\hline $\begin{array}{l}\text { Password sudah menjamin keamanan akses } \\
\text { software clipper.(V7) }\end{array}$ & 5 & 3.83 & 2 & 3.51 & -0.32 \\
\hline Output software clipper mudah dimengerti. & 6 & 3.80 & 6 & 3.23 & -0.57 \\
\hline (V10) & 7 & 3.74 & 9 & 2.74 & -1.00 \\
\hline $\begin{array}{l}\text { Data dan laporan keuangan yang diperoleh } \\
\text { sesuai dengan standar akuntansi (V1) }\end{array}$ & 8 & 3.46 & 7 & 2.97 & -0.49 \\
\hline $\begin{array}{l}\text { Informasi yang dihasilkan sudah jelas dan } \\
\text { tepat. (V4) }\end{array}$ & 9 & 3.46 & 8 & 2.80 & -0.66 \\
\hline $\begin{array}{l}\text { Penggunaan software clipper dapat menghemat } \\
\text { waktu dalam pelaporan keuangan. (V5) }\end{array}$ & & & & & \\
\hline $\begin{array}{l}\text { Software clipper dapat melakukan perhitungan } \\
\text { dengan tepat. (V2) }\end{array}$ & 10 & 3.14 & 10 & 2.54 & -0.60 \\
\hline
\end{tabular}

\begin{tabular}{|c|c|c|c|c|c|}
\hline \multirow{2}{*}{ Variabel } & \multicolumn{2}{|c|}{ Harapan } & \multicolumn{2}{c|}{ Kenyataan } & \multirow{2}{*}{ Gap } \\
\cline { 2 - 5 } & Rank & Mean & Rank & Mean & \\
\hline Penggunaan software clipper user friendhy. & 1 & 4.43 & 3 & 3.49 & -0.94 \\
(V8) & 2 & 4.06 & 5 & 3.31 & -0.75 \\
$\quad$ Informasi yang dihasilkan sudah lengkap dan & & & & & \\
sesuai yang diinginkan. (V3) & 3 & 3.91 & 1 & 3.63 & -0.28 \\
$\quad$ Mudah untuk penginputan data. (V9) & 4 & 3.89 & 4 & 3.43 & -0.46 \\
$\quad \begin{array}{l}\text { Penggunaan software clipper dapat menghemat } \\
\text { biaya yang dibutuhkan dalam laporan keuangan }\end{array}$ & & & & & \\
(V6) & & & & & \\
\hline
\end{tabular}


Berdasarkan informasi yang ditampilkan pada tabel diatas, dapat diketahui bahwa seluruh variabel memiliki nilai gap negatif. Gap terbesar terdapat pada variabel pertama yaitu "Data dan laporan keuangan yang diperoleh sesuai dengan standar akuntansi" dengan nilai gap sebesar -1, sedangkan gap terkecil terdapat pada variabel ke sembilan yaitu "Mudah untuk penginputan data" dengan nilai gap sebesar -0.28. Table Analisis Gap software Clipper per dimensi

\begin{tabular}{|l|c|c|c|c|c|}
\hline \multirow{2}{*}{ Dimensi } & \multicolumn{2}{|c|}{ Harapan } & \multicolumn{2}{c|}{ Kenyataan } & \multirow{2}{*}{ Gap } \\
\cline { 2 - 5 } & Rank & Mean & Rank & Mean & -0.60 \\
\hline Kegunaan & 1 & 4.05 & 2 & 3.45 & -0.32 \\
Integritas & 2 & 3.83 & 1 & 3.51 & -1.00 \\
Keakuratan & 3 & 3.74 & 5 & 2.74 & -0.56 \\
Efisiensi & 4 & 3.675 & 3 & 3.11 & -0.61 \\
Kehandalan & 5 & 3.55 & 4 & 2.94 & \\
\hline
\end{tabular}

Berdasarkan informasi yang ditampilkan pada tabel diatas, dapat diketahui bahwa seluruh dimensi memiliki nilai gap negatif. Gap terbesar terdapat pada dimensi keakuratan dengan nilai gap sebesar -1.00 , sedangkan gap terkecil terdapat pada dimensi integritas dengan nilai gap sebesar -0.32 .

\section{Grafik perbandingan keseluruhan variabel}

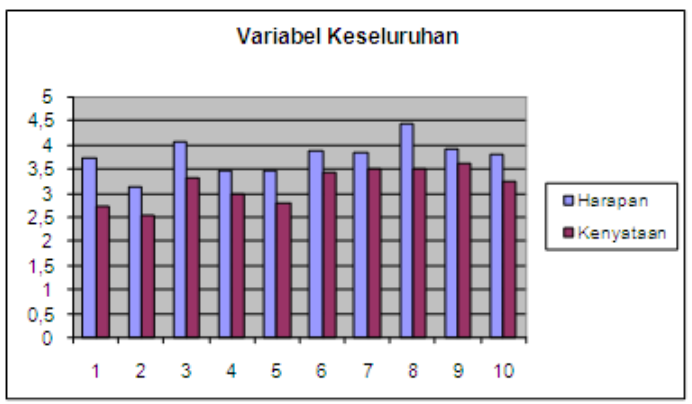

Gambar Grafik perbandingan keseluruhan variabel

Dari grafik ini dapat dilihat bahwa pada seluruh variabel, nilai harapan user lebih tinggi daripada nilai kenyataannya. Pada diagram ini dapat dilihat bahwa harapan user berkisar antara 3.14 (variabel 2) sampai dengan 4.43 (variabel 8) yang berarti bahwa user menaruh harapan yang tinggi pada variabel-variabel tersebut. Dan kenyataannya 2.54 (variabel 2) sampai dengan 3.63 (variabel 9) yang berarti user merasa tidak puas terhadap variabel-variabel tersebut.

\section{Grafik perbandingan keseluruhan dimensi}




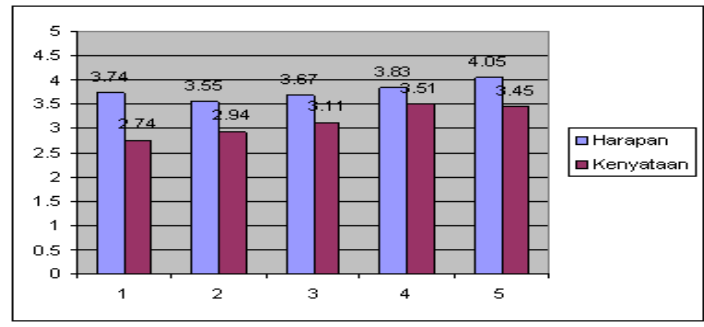

Gambar Grafik perbandingan keseluruhan dimensi

Dari grafik ini dapat dilihat bahwa pada seluruh dimensi, nilai harapan user lebih tinggi daripada nilai kenyataannya. Pada diagram ini dapat dilihat bahwa harapan user berkisar antara 3.55 (dimensi 2) sampai dengan 4.05 (dimensi 5) yang berarti bahwa user menaruh harapan yang tinggi pada dimensi-dimensi tersebut. Dan kenyataannya 2.74 (dimensi 1) sampai dengan 3.51 (dimensi 4) yang berarti user merasa tidak puas terhadap dimensi-dimensi tersebut.

\section{Pembahasan Hasil Penelitian}

\section{Harapan}

$\overline{\mathrm{Y}}$

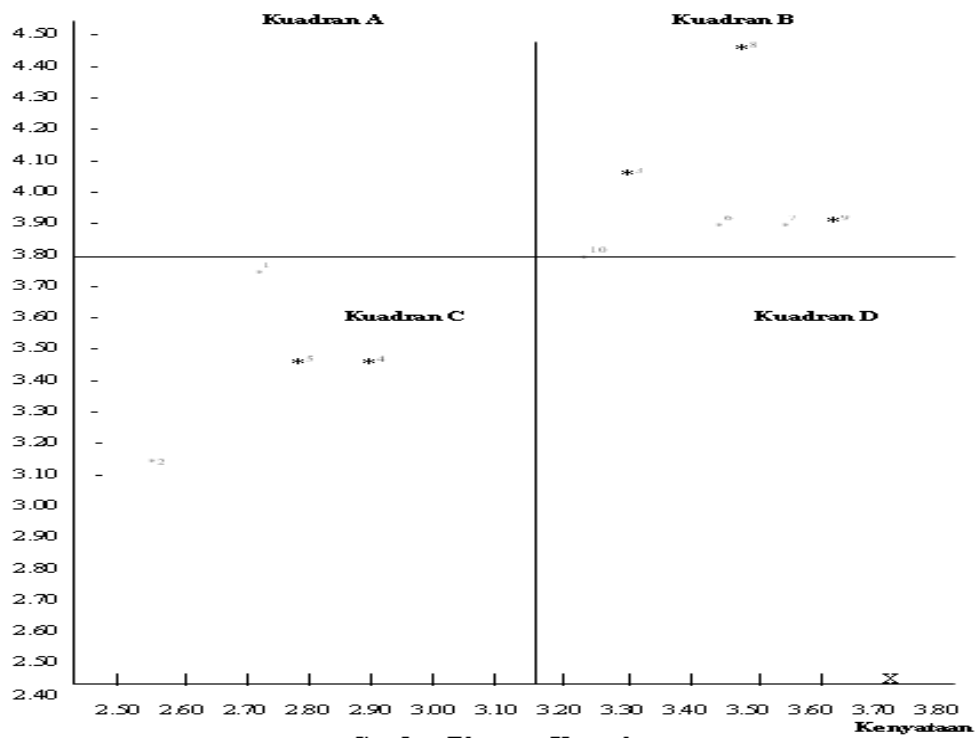

Gambar Diagram Kartesius 


\section{Penutup}

Berdasarkan analisis gap, dimana hasilnya menunjukkan bahwa seluruh gap dari seluruh pertanyaan adalah bernilai negatif, maka dapat disimpulkan bahwa pada seluruh pertanyaan tersebut, nilai harapan adalah lebih besar daripada nilai kenyataan. Berdasarkan analisis dari diagram kartesius, dimana hasilnya menunjukkan bahwa:

1. Faktor - faktor yang berada di kuadran B, yang merupakan faktor-faktor yang perlu dipertahankan pelaksanaanya, antara lain :

a. Butir ke-3, yaitu : Informasi yang dihasilkan sudah lengkap dan sesuai yang diinginkan.

b. Butir ke-6, yaitu : Penggunaan software clipper dapat menghemat biaya yang dibutuhkan dalam laporan keuangan.

c. Butirke-7, yaitu: Password sudah menjamin keamanan akses software clipper.

d. Butir ke-8, yaitu : Penggunaan software clipper user friendly.

e. Butir ke-9, yaitu: Mudah untuk penginputan data.

f. Butir ke-10, yaitu: Output software clipper mudah dimengerti.

2. Faktor-faktor yang berada di kuadran C, yang merupakan faktor-faktor yang dinilai kurang penting oleh user, tetapi telah dilakukan dengan cukup baik, antara lain:

a. Butir ke-1, yaitu : Data dan laporan keuangan yang diperoleh sesuai dengan standar akuntansi.

b. Butir ke-2, yaitu : Software clipper dapat melakukan perhitungan dengan tepat.

c. Butir ke-4, yaitu : Informasi yang dihasilkan sudah jelas dan tepat.

d. Butir ke-5, yaitu : Penggunaan software clipper dapat menghemat waktu dalam pelaporan keuangan.

Simpulan yang ditarik secara keseluruhan, berdasarkan pada analisis gap, dan analisis diagram kartesius, maka dapat disimpulkan bahwa pada dasarnya user merasa tidak puas dengan kinerja software yang sedang berjalan sekarang ini, tetapi masih mempunyai harapan agar kinerja software tersebut dapat lebih ditingkatkan lagi.

\section{DAFTAR PUSTAKA}

1. Daniel, Galin. (2004). Software Quality Assurance, From theory to implementation, Pearson, Adisson Wesley. 
2. Kotler, Philip. (2003). Marketing Management, $11^{\text {th }}$ Edition. Prentice Hall, New Jersey.

3. Remenyi, Dan; Money, Arthur, Sherwood Smith, Michael. (2000). Efective] Measurement \& Management of IT Cost \& Benefits, Second Edition. Computer Weekly.

4. Supranto, J. (2001). Pengukuran Tingkat Kepuasan Pelanggan untuk Menaikan Pangsa Pasar. Rineka Cipta, Jakarta.

http://library.gunadarma.ac.id/files/disk1/3/jbptgunadarma-gdl-s2-2004ekasariokt-124-babii.pdf 